\section{Hospitalizations of children due to primary health care sensitive conditions in Pernambuco State, Northeast Brazil}

\author{
Internações hospitalares de crianças por condições \\ sensíveis à atenção primária à saúde em \\ Pernambuco, Nordeste do Brasil
}

\author{
Hospitalizaciones de niños por condiciones \\ sensibles a la atención primaria de salud en el \\ Estado de Pernambuco, Nordeste de Brasil
}

\author{
${ }^{1}$ Instituto de Saúde Coletiva, \\ Universidade Federal da \\ Bahia, Salvador, Brasil. \\ Correspondence \\ S. C. Carvalho \\ Ladeira do Acupe 924, apto. \\ 501, Salvador, $B A$ \\ 40290-160, Brasil. \\ suzanaccarvalho@gmail.com
}

\begin{abstract}
Admissions due to primary health care sensitive conditions from 1999 to 2009 among children < 5 years old were analyzed for municipalities in Pernambuco State, Brazil. Using data from the Brazilian Unified National Health System's Hospital Information System, a negative binomial regression was applied to estimate rate ratio $(R R)$ and $95 \%$ CI for the effect on primary health care sensitive condition rates (admissions/10,000 inhabitants) of the Family Health Program (FHP) coverage (\%), some demographic variables and living conditions. Hospitalizations due to primary health care sensitive conditions represented $44.1 \%$ of 861,628 admissions and the rate declined from 557.6 to 318.9 (-42.8\%), a reduction three times greater than the rate due to all other causes. Increased FHP coverage was protective against primary health care sensitive conditions ( $R R=0.94$; 95\%CI: 0.89-0.99). A decline in hospitalizations due to primary health care sensitive conditions indicated improvements in health status and may be associated with the consolidation of primary health care. Studies on access and quality of primary health care in relation to child morbidity and hospitalizations are needed.
\end{abstract}

Hospitalization; Primary Health Care; Family Health Strategy; Child Health
Suzana Costa Carvalho 1

Eduardo Mota 1

Inês Dourado 1

Rosana Aquino 1

Carlos Teles 1

Maria Guadalupe Medina ${ }^{1}$

\section{Resumo}

Analisaram-se as internações por condições sensíveis à atenção primária de 1999-2009 em crianças < 5 anos, em municípios de Pernambuco, Brasil. Com dados do SIH/SUS, aplicou-se regressão binomial negativa para estimar razão de taxas e IC95\% do efeito sobre a taxa de internações por condições sensiveis à atenção primária (internações/10.000 habitantes) da cobertura (\%) do Programa Saúde da Família (PSF), variáveis demográficas e de condições de vida. Do total de 861.628 internações, 44,1\% foram por condições sensivveis à atenção primária. A taxa variou de 557,6 para 318,9 (-42,8\%), redução 3 vezes maior que da taxa de internação por todas as outras causas. Maior cobertura do PSF teve efeito protetor contra internações por condições sensíveis à atenção primária (razão de taxa= 0,94; IC95\%: 0,89-0,99). A diminuição de internações por condições sensíveis indicou melhoria na situação de saúde e pode estar associada à consolidação do PSF. Há necessidade de estudar acesso e qualidade da atenção primária à saúde em relação à morbidade e hospitalizações.

Hospitalização; Atenção Primária à Saúde; Estratégia Saúde da Família; Saúde da Criança 


\section{Introduction}

According to some evidence, effective health promotion practices and early and adequate care might reduce the occurrence of severe cases of disease and consequently decrease the need for hospital admissions and highly complex and costly treatments 1,2 . Service organization models that prioritize primary health care are supposed to impact the number and characteristics of hospital admissions ${ }^{3}$. Among the proposals for organizing primary health care in Brazil, the Family Health Program (FHP) stands out as one of the pillars of health policy, also considered to be the preferential door of entry to services of the Brazilian Unified National Health System (SUS) 4. The FHP provides coverage to approximately $54.8 \%$ of the Brazilian population as a whole and $72.6 \%$ of the northeastern region (as of December 2012). Those proportions are the result of the adherence to the FHP of all states and more than $90 \%$ of the municipalities as well as to a relatively quick expansion of the program, which increased the population's access to services.

With this, the recognition of the potential preventability of certain diseases through primary care 5 led some authors, from 2005 onwards, to formulate the Brazilian list of hospitalizations due to primary care sensitive conditions, i.e., a set of health problems for which the need for hospital admission might be avoided with effective, timely and high-quality actions performed at the primary care level 6 . Specifically, this concept was based on a study from the early 1990s 7 , which aimed to understand the barriers to outpatient care according to socioeconomic conditions, using the causes of hospitalization as indicators of access and quality of services at the primary health care level. In 2008, the Brazilian Ministry of Health issued a directive listing those conditions 8 which was also published in a scientific article in 2009 6. From that time onwards, the rate of hospitalizations due to primary care sensitive conditions has been used to assess the effectiveness of primary health care 9,10,11. In fact, more recent studies have found an association between the rate of hospitalizations due to primary care sensitive conditions and the expansion of FHP coverage 12,13,14. In 2010, FHP coverage reached $68.3 \%$ of the population of Pernambuco State, as a consequence of the rapid expansion of that program since its establishment in that state in 1998. Thus, after a decade, a substantial reduction in avoidable hospital admissions might be expected.

In the last two decades, a positive change with regard to health care, living conditions and social determinants has been observed and has hap- pened in parallel with reductions in mortalities among children, including those under the age of five. Despite these advances, some challenges remain, including: regional inequalities in the population distribution of infant deaths, the increase in preterm births and high proportions of deaths and hospital admissions due to preventable causes 15 . Faced with so many challenges, attention to the health problems of children remains a priority, since reducing infant mortality was one of the Brazilian commitments to the Millennium Development Goals. The present article describes the results of a study that assessed the temporal evolution of rates of hospitalizations due to primary care sensitive conditions in children under the age of five in Pernambuco State, Northeast Brazil, taking into consideration changes in FHP coverage and other factors.

\section{Methods}

This exploratory study adopted an ecological and longitudinal approach in which a panel data technique was used. Municipalities were the units of analysis, and all 185 Pernambuco municipalities were included. The study included children aged under five residing in that state who were admitted to hospitals providing services to SUS and located in that state, between 1999 to 2009. During that period, the FHP was firmly established as the structuring strategy of the healthcare model. The study comprised young children, given the vulnerability of that group to avoidable causes of hospital admission. In Pernambuco in 1999, there was a total of 774,625 individuals in that age group, corresponding to $10.3 \%$ of the state population; this proportion progressively decreased to 8.7\% in 2009 (Health Informatics Department DATASUS. http://www2.datasus.gov.br, accessed on 23/Mar/2013).

Data registered in the SUS Hospital Information System (SIH/SUS) was used and stored in digital databases openly available in the DATASUS website (http://tabnet.datasus.gov.br/ cgi/sih/midescr.htm, accessed on 23/Mar/2013), as well as census data provided by the Brazilian Institute of Geography and Statistics (IBGE), accessed in June 2011. Only paid Hospital Admission Authorizations (AIH) were included in the analysis. The causes of the hospitalizations recorded on the AIH forms were classified according to the Brazilian List of Primary Care Sensitive Conditions 8 , which reflects the concept of hospitalization due to primary care sensitive conditions used in the present study. That list describes 74 selected causes of hospitalizations distributed in 19 groups and is based on the 10th revision 
of the International Statistical Classification of Diseases (ICD-10). All other causes of hospital admission were classified as non-hospitalization due to primary care sensitive conditions. Admissions for delivery and birth were excluded. The rates of admissions for both hospitalizations due to primary care sensitive conditions (dependent variable) and non-hospitalization due to primary care sensitive conditions per 10,000 children were calculated by dividing the number of hospitalizations for children under five by the total number of children within that age range per municipality and year.

FHP coverage was defined as the percentage of individuals assisted by that program. That indicator was calculated based on the recommendations of the Department of Primary Care at the Brazilian Ministry of Health (http://dab.saude. gov.br/index.php, accessed on 11/Mar/2011), according to which the average number of individuals assisted per FHP team is 3,450 (i.e., 1,000 families with an average of 3.45 members). The proportion of the population covered by the FHP in the state and for each municipality per year was calculated by multiplying the number of FHP teams by the mean number of individuals assisted by one FHP team, and the result was then divided by the total population. That variable was categorized as follows, based on previously published criteria 16 , but with modifications: FHPs with a consolidated population coverage (namely covering $70 \%$ or more of the population and established in the municipality for four or more years); FHPs with intermediate coverage (coverage $70 \%$ or more of the population and established in the municipality for less than four years or covering between $30 \%$ and $70 \%$ of the population irrespective of time since establishment); and FHPs with incipient coverage (less than 30\%).

The following variables (obtained by $\mathrm{mu}$ nicipality and year) were also included in the analysis: demographic characteristics and living conditions (the proportion of children under five 16 , the illiteracy rate among those aged 15 and over and the proportion of poor individuals (according to the classification of the Institute for Applied Economic Research - IPEA. Ipeadata. http://www.ipea.gov.br/portal/, accessed on 29/Aug/2011), the Child Development Index (CDI) 17, the Municipal Human Development Index (HDI-M) 18 and the proportion of the population with piped water at home according to the censuses of 1991 and 2000, and the supply and use of health care services (the availability of hospitals and the proportion of live born infants whose mothers attended up to three prenatal visits as recorded by the Information System on
Live Births (SINASC. http://tabnet.datasus.gov. br/cgi/deftohtm.exe?sinasc/cnv/nvuf.def, accessed on 23/Mar/2013). The CDI is a synthetic indicator calculated by the United Nations Children's Fund (UNICEF), which helps to formulate and monitor targeted early childhood public policies. It consists of four basic indicators: number of children less than six years old living with poorly educated parents, vaccination coverage in children under one year of age, prenatal coverage of pregnant women and children enrolled in preschool ${ }^{17}$. It is known that the higher the CDI and HDI-M values the better the living conditions of the population. The availability of hospitals was dichotomized (present and absent), while the other variables were categorized according to distribution quartiles.

To compensate for the lack of municipality level data for some years, the following variables had values interpolated: the CDI, the HDI-M, the proportion of poor people, the illiteracy rate and the proportion of population with piped water at home. A linear trend hypothesis was adopted to find intermediate values between two data points to determine the annual change in the values of the variables (either the census years, 1991 and 2000, or any pair of years of the series). Further, extrapolation made it possible to obtain data for the full period from 1999 to 2009. A similar approach was used in another study of the FHP 16: for 17 municipalities that had not yet been created by the time of the 1991 census, the data from the health region to which they were to belong was used as the 1991 initial time-point and their own 2000 census data were taken as the second time-point for interpolation. Data on hospital availability was accessible for 1999 , 2002 and 2005-2009; for the other years, it was assumed that the hospitals existed in a municipality in 2000 and 2001 when there were records of it in 1999 and 2002; likewise for 2003 and 2004, when records from 2002 and 2005 were available.

The relative importance of the effects of the independent variables on the temporal variation in the rate of hospitalizations due to primary care sensitive conditions was analyzed by applying a fixed-effects negative binomial regression. That method was selected because it is appropriate for count data that exhibits over-dispersion 19, as was the case of the rate of hospitalizations due to primary care sensitive conditions. That technique also allows the regression intercept to be attributed to each unit of analysis to operate as its control 19,20 . The fixed-effects model was chosen, based on the Hausman test and because it is the most appropriate for assessing panel data. The fixed-effects model was also adopted by other studies that have assessed the impact 
of the FHP 13,14,16 and thus allows our results to be compared. Goodness of fit tests with Akaike Information Criterion and Bayesian Information Criterion estimates were done.

Data from all 185 municipalities for the entire 11 year period were integrated into the regression analysis. This resulted in a total of 2,035 entries. The associations between the hospitalizations due to primary care sensitive conditions rate and the study variables were investigated by calculating the rate ratio (RR) and 95\% confidence interval $(95 \% \mathrm{CI})$ of rates of hospitalizations due to primary care sensitive conditions by exposure categories of municipality entries, considering those rates as cumulative incidence of hospitalization. A bivariate analysis was performed first to investigate the association between the rate of hospitalizations due to primary care sensitive conditions and each independent variable, and the variables that exhibited a $\mathrm{p}$-value significance level equal to or lower than $10 \%$ were included in the multivariate analysis. The variables with co-linear behavior were excluded from the final model. The application TabWin 3.2 (DATASUS. http://portal.saude.gov.br/portal/se/datasus/ area.cfm?id_area=732) was used for data tabulation, while Stata/SE 10.0 (Stata Corp., College Station, USA) was applied for the descriptive and multivariate analyses.

\section{Results}

Of 861,628 hospital admissions for children under five recorded in Pernambuco from 1999 to $2009,44.1 \%(380,060)$ were due to primary care sensitive conditions. The proportion of hospitalizations due to primary care sensitive conditions relative to the total number of hospital admissions varied annually, ranging from a maximum of $47.8 \%$ (in 2003) to a minimum of $37.7 \%$ (in 2009). The rate of hospital admissions for all causes decreased by $27.8 \%$ in that period (from $1,170.8$ to $845.5 / 10,000$ children). The rate of hospitalizations due to primary care sensitive conditions showed a continuous decline starting in 2003, dropping from 557.6 to 318.9 (-42.8\%). Although the non-hospitalizations due to primary care sensitive conditions rate decreased from 613.2 to $536.4(-14.2 \%)$, it did not occur in a progressive manner. The reduction of the hospitalizations due to primary care sensitive conditions rate was threefold greater compared to the reduction of the non-hospitalization due to primary care sensitive conditions rate (Figure 1).

All 19 groups of causes of the Brazilian List of Primary Care Sensitive Conditions 8 were registered for hospital admissions of children.
The two groups responsible for the highest proportion of hospitalizations due to primary care sensitive conditions were gastroenteritis and complications (Gastroenteritis A00 to A09 and Dehydration E86) and asthma (Asthma J45, J46), while the third position varied between bacterial pneumonia (notably, Other Bacterial Pneumonia and unspecified J15.8, J15.9) and respiratory diseases (Acute Bronchitis J20, J21, specially) in alternate years. The results indicated that most hospital admissions were due to a small number of causes that together accounted for $89.1 \%$ of all cases (varying from $93.1 \%$ in 1999 to $82.1 \%$ in 2009). In addition, those two main groups of conditions (gastroenteritis and asthma) accounted for $85.4 \%, 76.9 \%$ and $63 \%$ of hospitalizations due to primary care sensitive conditions in 1999, 2004 and 2009, respectively (Table 1 ).

The FHP coverage increased $321.7 \%$ (IPEA. Ipeadata. http://www.ipea.gov.br/portal/, accessed on 29/Aug/2011) in Pernambuco during the period under study, with three distinct phases of progression. The greatest expansion occurred from 1999 to 2001 ( $16.5 \%$ to $44.1 \%$ ), followed by a phase of slower growth from 2001 to 2005 (44.1\% to $62.6 \%$ ) and culminating in a stabilization phase, with coverage reaching $67.9 \%$ by 2009 . The number of municipalities with consolidated FHP coverage showed continuous growth, reaching $80 \%$ in the last year of the series, when FHP coverage was classified as intermediate in $19.5 \%$ of the municipalities and as incipient in a single municipality (Figure 2).

A bivariate regression analysis (Table 2) showed that the hospitalizations due to primary care sensitive conditions rate in those municipalities with intermediate FHP coverage was $12 \%$ lower than those with incipient FHP coverage, which was considered the reference group for the analysis (RR $=0.88$; 95\%CI: 0.85-0.91). Conversely, the rate of hospitalizations due to primary care sensitive conditions in the municipalities with consolidated FHP coverage was 30\% lower than the rate of the reference group ( $\mathrm{RR}=0.70$; 95\%CI: 0.67-0.73). The protective effect of FHP against preventable hospital admissions was confirmed by the final adjusted model. Indeed, the hospitalization due to primary care sensitive conditions rates in the municipalities with intermediate and consolidated FHP coverage were, respectively, $4 \%$ and $6 \%$ lower than those with incipient coverage. The final multivariate model showed that the municipalities with low HDI-M values exhibited hospitalization due to primary care sensitive conditions rates that were $69 \%$ higher than those with high HDI-M values. The illiteracy rate and the proportion of the population under five were positively correlated with the rate of hospitaliza- 
Figure 1

Hospital admission rates and rate ratios for non-hospital admissions for primary care sensitive conditions and hospital admissions for primary care sensitive conditions among children under five residing in Pernambuco State, Northeast Brazil, per year, 1999 to 2009.

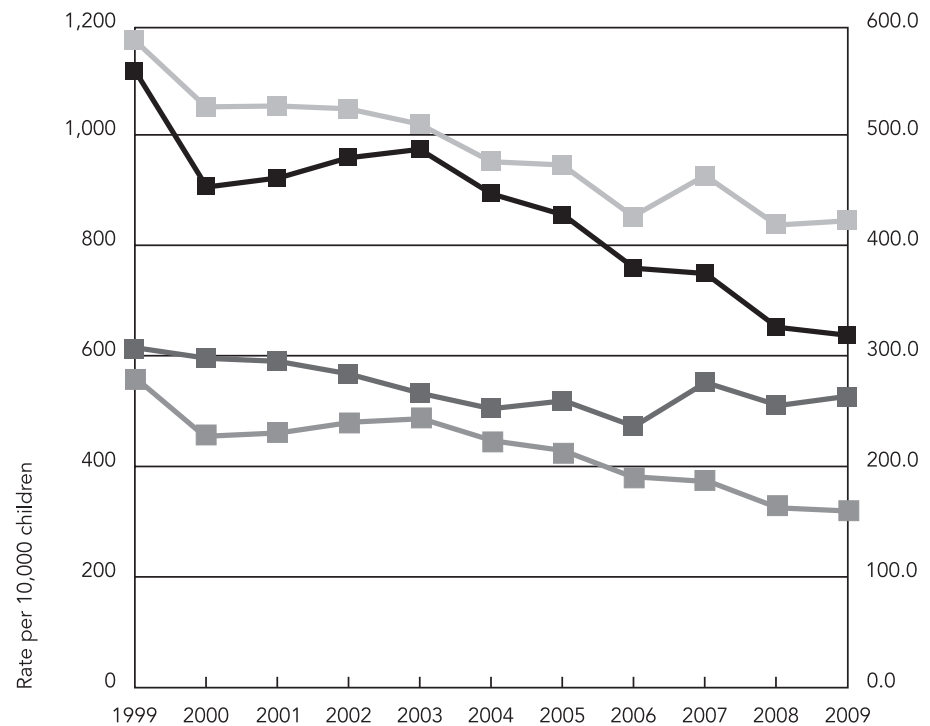

00.0

00.0

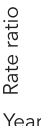

- Overall hospital admission rate

- Non-hospitalizations due to primary care sensitive conditions rate

$\rightarrow$ Hospitalizations due to primary care sensitive conditions rate

- Rate ratio

Source of data on hospital admissions: Hospital Information System, Brazilian Unified National Health System (SIH/SUS) (Health Informatics Department DATASUS. http://tabnet.datasus.gov.br/cgi/sih/midescr.htm, accessed on 23/Mar/2013).

Hospital admissions for primary care sensitive conditions rate: number of hospital admissions for primary care sensitive conditions among children under five divided by the total population within that age range per 10,000 inhabitants; Non-hospital admissions for primary care sensitive conditions: hospital admissions for other causes; Rates: number of hospital admissions (hospital admissions for primary care sensitive conditions, non-hospital admissions for primary care sensitive conditions and overall) in children under five divided by the total population within that age range per 10,000 inhabitants.

tions due to primary care sensitive conditions. The proportion of the population with access to piped water was negatively associated with the rate of hospitalizations due to primary care sensitive conditions (Table 2).

Some variables were not retained in the final regression model: the proportion of poor people and the CDI, which predicted a higher rate of hospitalizations due to primary care sensitive conditions in the bivariate analysis but exhibited co-linear behavior with other variables in the adjusted model, and the presence of hospitals in the municipality, which did not attain statistical significance in the multivariate analysis.

\section{Discussion}

The reduction in the rate of hospital admissions for children younger under five in Pernambuco from 1999 to 2009 was greater for primary care sensitive conditions than for all other causes of hospitalization. Based on our data, it was esti- mated that at least 18,000 avoidable hospital admissions were avoided at SUS-affiliated hospitals. Thus reducing hospitalizations due to primary care sensitive conditions is beneficial for children and their families, the population at large and the SUS administration because unnecessary expenses are avoided and the social burden of morbidity is reduced.

Improvements in social conditions and increased FHP coverage may have simultaneously influenced the reduction in hospitalizations due to primary care sensitive conditions. It may be considered also that the changes in the healthcare model, principally the expansion of FHP coverage, might have improved the overall living and health conditions of the target population. Evidence of this can be inferred from the dramatic reduction in the under-five mortality rate (deaths of children under five per 1,000 live births) in Pernambuco that dropped from 49.3 in 2000 to 20.9 in 2009 (http:/ / www2.datasus.gov.br, accessed on 23/Mar/2013). In fact, it was found that even for those municipalities with interme- 
Number and proportion of hospital admissions due to primary care sensitive conditions for the most frequent causes in children under five residing in Pernambuco State, Northeast Brazil.

\begin{tabular}{|c|c|c|c|c|c|c|}
\hline \multirow{3}{*}{ Cause groups * } & \multicolumn{6}{|c|}{ Year } \\
\hline & \multicolumn{2}{|c|}{1999} & \multicolumn{2}{|c|}{2004} & \multicolumn{2}{|c|}{2009} \\
\hline & $\mathrm{n}$ & $\%$ & $\mathrm{n}$ & $\%$ & $\mathrm{n}$ & $\%$ \\
\hline Infectious gastroenteritis and complications & 25,153 & 58.2 & 18,778 & 50.6 & 10,971 & 44.9 \\
\hline Asthma & 11,725 & 27.1 & 9,748 & 26.3 & 4,412 & 18.1 \\
\hline Bacterial pneumonia & 320 & 0.7 & 2,828 & 7.6 & 1,593 & 6.5 \\
\hline Respiratory diseases & 2,999 & 6.9 & 1,786 & 4.8 & 3,060 & 12.5 \\
\hline $\begin{array}{l}\text { Other causes of hospitalizations for primary care } \\
\text { sensitive conditions }\end{array}$ & 2,999 & 6.9 & 3,950 & 10.6 & 4,377 & 17.9 \\
\hline $\begin{array}{l}\text { Total hospitalizations for primary care sensitive } \\
\text { conditions }\end{array}$ & 43,196 & 100.0 & 37,090 & 100.0 & 24,413 & 100.0 \\
\hline $\begin{array}{l}\text { Non-hospitalizations for primary care sensitive } \\
\text { conditions }\end{array}$ & 47,506 & & 41,902 & & 40,289 & \\
\hline Hospital admissions ratio & & & & & & \\
\hline
\end{tabular}

Source of data on hospital admissions: Hospital Information System, Brazilian Unified National Health System

(Health Informatics Department - DATASUS. http://www2.datasus.gov.br, accessed on 23/Mar/2013).

* Cause groups according to hospitalizations for primary care sensitive conditions 8 based on the International Statistical

Classification of Diseases, 10th Revision.

Non-hospitalizations for primary care sensitive conditions: hospital admissions for all other causes

Admissions for births (87) were excluded.

diate FHP coverage, the protective effect of that program against hospitalization due to primary care sensitive conditions seemed evident. However, if primary care is to be considered a strategic element in changing the healthcare model, in providing universal coverage and is thus to be the entry door of the health service system, then the implementation of consolidated coverage of the FHP is called for, as is the case for the majority of the municipalities in the state.

The relationship between the expansion of access to healthcare services and other social and economic public policies is well known. It is worth noting that the decade investigated in the present study was marked by substantial improvements in the living conditions in Pernambuco, as reflected by the increases in the HDI-M (18\%) 18 , the CDI $(47.6 \%) 17$ and the proportion of the population with piped water at home (8.9\%) (http://www2.datasus.gov.br, accessed on 23/Mar/2013), and reductions in the illiteracy rate $(-38.9 \%)$ and the proportion of poor people (-14.6\%) (IPEA. Ipeadata. http://www. ipea.gov.br/portal/, accessed on 29/Aug/2011). Indeed, the reduction in the rate of hospitalizations due to primary care sensitive conditions was correlated with the social and economic determinants of the living and health conditions analyzed in the present study, and this result aligns with the findings reported by other studies 10,14. Moreover, some investigations found negative associations between the indicators of living conditions and child mortality attributable to avoidable causes 21 , family income and hospital admissions of children 22 as well as between schooling and child mortality 23 and hospitalizations due to primary health care sensitive conditions $10,12,24,25$.

The observed decline in the hospitalization due to primary care sensitive conditions rate was greater than the ones reported for other age ranges in Pernambuco and in the Brazilian Northeast 14. This finding lends support to the role of the FHP in the control of diseases among children, a target group for activities at the primary level of the health care system. The FHP prioritizes immunization, the early diagnosis and timely treatment of acute disorders to avoid complications (e.g., in the case of gastroenteritis) and to achieve the control of chronic diseases (e.g., asthma) 1,5. This role is consistent with the goals of reorganizing the healthcare model, by promoting changes in the organization of services and health practices and strengthening, expanding and increasing the quality of primary care 26,27 . 
Figure 2

Family Health Program (FHP) coverage (\%) in the state and proportion of municipalities according to different categories of FHP coverage in Pernambuco State, Northeast Brazil, per year, 1999-2009.

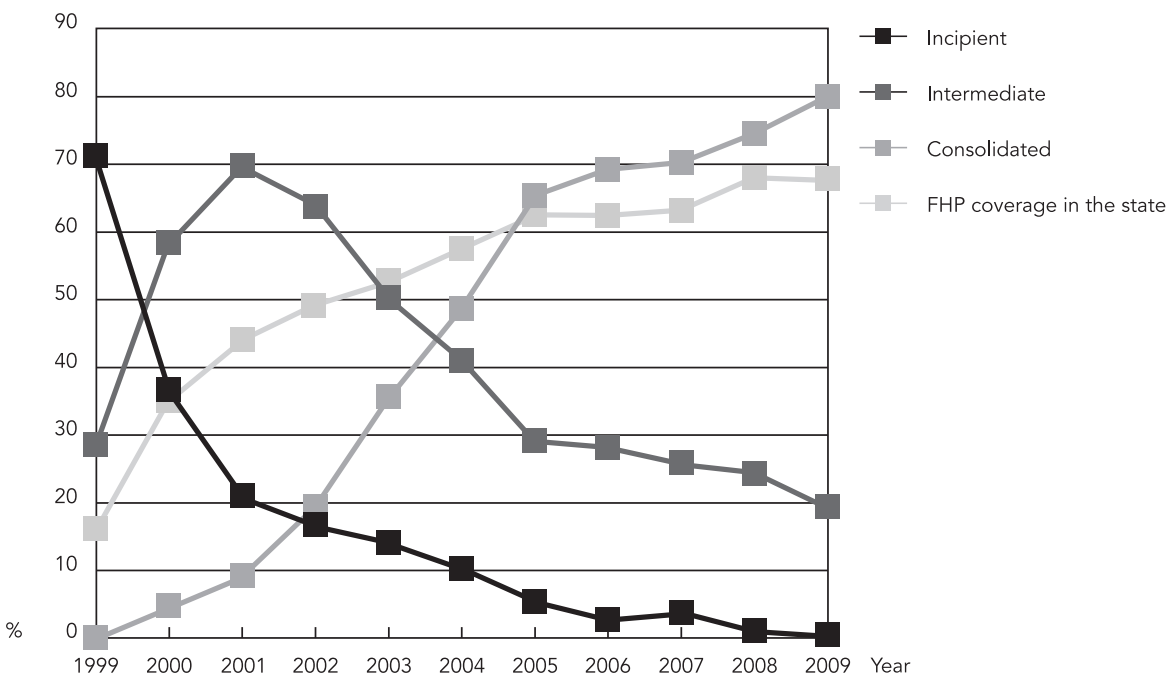

Source of data on FHP coverage: Department of Primary Care, Brazilian Ministry of Health. (History of family health coverage. http://dab.saude.gov.br/index.php, accessed on 11/Mar/2011).

Incipient: $<30 \%$ FHP coverage.

Intermediate: FHP coverage ( $\geq 70 \%$ and time since establishment $<$ four years) or FHP coverage $<70 \%$ and $\geq 30 \%$,

independent of the time since the establishment of the program.

Consolidated: FHP coverage $\geq 70 \%$ and time since establishment $>$ four years.

FHP coverage was calculated based on estimated number of individuals assisted by FHP teams divided by total population.

FHP coverage categorization was based on work by Aquino et al. 16.

Table 2

Crude and adjusted rate ratios (RR) obtained by negative binomial regression for the association of the hospitalizations for primary care sensitive conditions rate in children under five with Family Health Program (FHP) coverage and demographic data, living conditions and the supply and use of healthcare services in Pernambuco State municipalities, Northeast Brazil, 1999 to 2009

\begin{tabular}{|c|c|c|}
\hline \multirow[t]{2}{*}{ Variable } & Bivariate analysis & $\begin{array}{c}\text { Adjusted multivariate } \\
\text { analysis }\end{array}$ \\
\hline & RR $(95 \% \mathrm{Cl})$ & $\mathrm{RR}(95 \% \mathrm{Cl})$ \\
\hline \multicolumn{3}{|l|}{ FHP coverage * } \\
\hline Incipient & 1.00 & 1.00 \\
\hline Intermediate & $0.88^{* \star}(0.85-0.91)$ & $0.96^{\star \star \star}(0.93-0.99)$ \\
\hline Consolidated & $0.70 * \star(0.67-0.73)$ & $0.94 * \star \star(0.89-0.99)$ \\
\hline \multicolumn{3}{|c|}{ Percentage of population under five \# } \\
\hline$\leq 9.6$ & 1.00 & 1.00 \\
\hline$>9.6 \leq 10.5$ & $1.40 * *(1.31-1.49)$ & $1.19 * *(1.12-1.27)$ \\
\hline$>10.5 \leq 11.4$ & 1.69 ** $(1.57-1.83)$ & $1.25^{\star \star}(1.15-1.35)$ \\
\hline$>11.4$ & $2.08 * \star(1.90-2.27)$ & $1.30^{* \star}(1.17-1.43)$ \\
\hline
\end{tabular}

(continues) 
Table 2 (continued)

\begin{tabular}{|c|c|c|}
\hline \multirow[t]{2}{*}{ Variable } & Bivariate analysis & $\begin{array}{c}\text { Adjusted multivariate } \\
\text { analysis }\end{array}$ \\
\hline & $\mathrm{RR}(95 \% \mathrm{Cl})$ & $\mathrm{RR}(95 \% \mathrm{Cl})$ \\
\hline \multicolumn{3}{|c|}{ Illiteracy rate among those over the age of $15 \# \#$} \\
\hline$\leq 23.8$ & 1.00 & 1.00 \\
\hline$>23.8 \leq 30.5$ & 1.32 ** $(1.25-1.40)$ & $1.01(0.94-1.10)$ \\
\hline$>30.5 \leq 36.6$ & $1.77^{\star \star}(1.66-1.88)$ & $1.10^{\star \star \star}(1.00-1.20)$ \\
\hline$>36.6$ & $2.31 \star \star(2.15-2.48)$ & $1.19 * *(1.05-1.34)$ \\
\hline \multicolumn{3}{|c|}{ Human Development Index \#\# } \\
\hline$\geq 0.712$ & 1.00 & 1.00 \\
\hline$\geq 0.667<0.712$ & 1.36 ** $(1.30-1.43)$ & $1.23 * \star(1.15-1.31)$ \\
\hline$\geq 0.624<0.667$ & $1.77 * *(1.67-1.87)$ & $1.44 * *(1.32-1.58)$ \\
\hline$<0.624$ & $2.32 * \star(2.18-2.47)$ & $1.69 * *(1.50-1.90)$ \\
\hline \multicolumn{3}{|c|}{ Proportion of population with piped water \# } \\
\hline$\geq 69.7$ & 1.00 & 1.00 \\
\hline$\geq 55.2<69.7$ & $1.28 * *(1.18-1.39)$ & $1.09 * \star \star(1.01-1.17)$ \\
\hline$\geq 39.2<55.2$ & $1.73 * \star(1.56-1.93)$ & $1.15 * *(1.04-1.28)$ \\
\hline$<39.2$ & $1.85 * \star(1.63-2.10)$ & $1.02(0.89-1.16)$ \\
\hline \multicolumn{3}{|c|}{ Proportion of live born infants whose mothers } \\
\hline \multicolumn{3}{|c|}{ attended 0 to 3 prenatal visits \# } \\
\hline$\leq 8.7$ & 1.00 & 1.00 \\
\hline$>8.7 \leq 13.6$ & $1.10 * \star(1.04-1.16)$ & $0.97(0.92-1.02)$ \\
\hline$>64.6 \leq 21.6$ & 1.35 ** $(1.28-1.42)$ & $1.02(0.96-1.08)$ \\
\hline$>21.6$ & $1.60 * \star(1.5-1.69)$ & $1.01(0.94-1.08)$ \\
\hline \multicolumn{3}{|c|}{ Child Development Index $\S$} \\
\hline$\geq 0.600$ & 1.00 & \\
\hline$\geq 0.508<0.600$ & 1.33 ** (1.27-1.39) & \\
\hline$\geq 0.425<0.508$ & 1.64 ** $(1.54-1.73)$ & \\
\hline$<0.425$ & $2.02 * \star(1.90-2.16)$ & \\
\hline \multicolumn{3}{|c|}{ Proportion of poor people \#\# } \\
\hline$\leq 55.6$ & 1.00 & \\
\hline$>55.6 \leq 64.2$ & $1.51 * *(1.41-1.62)$ & \\
\hline$>64.2 \leq 70.5$ & 1.88 ** $(1.73-2.06)$ & \\
\hline$>70.5$ & 2.41 ** $(2.19-2.66)$ & \\
\hline \multicolumn{3}{|l|}{ Hospital \# } \\
\hline Present & 1.00 & \\
\hline Absent & 0.82 ** $(0.78-0.87)$ & \\
\hline
\end{tabular}

95\%Cl: 95\% confidence interval; FHP: Family Health Program;

hospitalizations for primary care sensitive conditions rate: number of hospitalizations for primary care sensitive conditions among children $<$ five years old divided by the total population within that age range per 10,000 inhabitants.

* FHP coverage: Incipient ( $<30 \%$ ); Intermediate ( $\geq 70 \%$ and time since establishment $<$ four years) or $(<70 \%$ and $\geq 30 \%$ );

Consolidated ( $\geq 70 \%$ and time since establishment $\geq$ four years);

$\star * \quad p<0.01$;

*** $p<0.05$

\# Health Informatics Department (DATASUS. http://www2.datasus.gov.br, accessed on 23/Mar/2013);

\#\# Institute for Applied Economic Research - IPEA. Ipeadata. http://www.ipea.gov.br/portal/, accessed on 29/Aug/2011);

\#\# Secretaria de Desenvolvimento Social e Direitos Humanos 18;

$\S$ United Nations Children's Fund (UNICEF) 17.

Source of data on hospital admissions: Hospital Information System, Brazilian Unified National Health System - SIH-SUS (http://tabnet.datasus.gov.br/cgi/sih/midescr.htm, accessed on 23/Mar/2013).

The variables "proportion of poor people" and "Child Development Index" were not retained in the final regression model, because they exhibited co-linear behavior. The presence of hospitals in the municipality did not attain statistical significance in the multivariate analysis and did not remain in the final model.

Total corresponding to 185 municipalities per study year $(n=2,035)$. 
Gastroenteritis and respiratory diseases, which are strongly associated with socioeconomic and environmental circumstances, were the main causes of hospitalizations due to primary care sensitive conditions, and continue to represent a substantial health problem in the pediatric population despite the reduction in the rate of hospital admissions for those causes. It is worth noting that interventions targeting the factors associated with one or two diseases might lead to a significant reduction in hospitalizations due to primary care sensitive conditions: the present study showed that two clinical conditions (gastroenteritis and asthma) accounted for a large proportion of hospitalizations due to primary care sensitive conditions. It is also worth stressing the relevance of prioritizing health actions aimed at reducing child morbidity by avoidable causes with policies and programs that seek to increase the accessibility of services, the efficacy and quality of health care and interventions that address the social determinants of those conditions.

The results presented here should be interpreted with caution. First, there are known limitations in the data provided by SIH/SUS in terms of producing an accurate picture of disease frequency. For example, funding restrictions for the payment of hospital admissions might adversely affect the recording of cases in the database; partial coverage of hospital admissions by SUS, due to the use of private supplementary healthcare services, might result in an underestimation of the hospital admission rate; and multiple hospitalizations of the same individual in the same year are not known, since duplicated admissions were not taken into account. However, it was assumed that multiple hospitalizations are less common among young children mostly due to access barriers to hospital beds. The observation drawn in this study from the bivariate analysis that the absence of a hospital in the municipality was related to a lower value of hospitalizations due to primary care sensitive conditions might not be controversial, if we consider that the lack of a SUS-affiliated hospital in a given place represented an access barrier to health care by itself that, in turn, would result in hospitalization in a neighboring municipality or simply poor and incomplete local health care with or without any serious consequences. Nevertheless, the findings were consistent with other studies based on data provided by SIH/SUS. Certainly, its continued use contributes to improvements in data and lends support to the validity of the information 28 .

The limitations arising from the lack of data for some variables in each year and municipality studied led to the need for imputation by means of interpolation, which might have resulted in less precise estimates 29 . Moreover, the assumption of a linear relationship between any two time-points in the series ignores the possibility of variations occurring within the study period; thus, the predictive value of some variable might have been greater or smaller than the one eventually resulting from the analysis of a full set of original data if it was available. In the present study, imputation was performed for the socioeconomic variables that depict the overall conditions in Pernambuco, which in turn exhibited substantial improvements throughout the decade studied. Therefore, even though variations in the evolution of the indicators of interest might have actually occurred, the overall tendency exhibited by their values might have remained.

FHP coverage expanded significantly in Pernambuco (and across Brazil) thus increasing the access of the population to primary health care. The expansion and consolidation of the FHP in Pernambuco might have contributed to the reduction in the hospitalization due to primary care sensitive conditions rate, as this study showed. The results indicated that FHP is potentially relevant for reducing child morbidity and/or the severity of the health problems that affected young children, as other studies have shown 16,30,31,32. However, the indicator used (rate of hospitalizations due to primary care sensitive conditions) for the assessment of the conditions, effectiveness and capabilities of primary care in general, and of the FHP in particular, must be assessed in future studies aimed at evaluating the effects of health policies and programs. In particular, there is a need for studies comparing the patterns and trends in hospital admissions in different states and municipalities, including the characteristics of access to services, other indicators of living conditions and the coverage and quality of the services provided at the primary care level of health system. Following the quantitative expansion of the FHP the challenge is to consolidate the quality of its actions and to integrate it with the full network of SUS healthcare services and facilities. 


\section{Resumen}

Se analizaron las hospitalizaciones por condiciones sensibles a la atención primaria entre 1999-2009 en niños < 5 años en municipios de Pernambuco, Brasil. Se aplicó una regresión binomial negativa a los datos del Sistema de Información Hospitalaria del SUS para estimar la razón de tasas (RT) y un IC95\% de los efectos sobre la tasa de hospitalizaciones por condiciones sensibles (hospitalizaciones/10.000 habitantes) de la cobertura (\%) del Programa de Salud de la Familia $(P S F)$, variables demográficas y de condiciones de vida. Del total de 861.628 admisiones, un 44,1\% eran hospitalizaciones por condiciones sensibles. La tasa varió de 557,6 a 318,9 (-42,8\%), reducción tres veces mayor que la tasa por todas las otras causas. Una mayor cobertura del PSF fue protectora contra hospitalizaciones por condiciones sensibles ( $R T=0,94$; 95\%IC: 0,89-0,99). La disminución de hospitalizaciones por condiciones sensibles indica una mejoría de condiciones de salud y puede estar asociada con el PSF Se señala la necesidad de estudiar el acceso y la calidad de la atención primaria de salud, en relación con la morbilidad y hospitalizaciones.

Hospitalización; Atención Primaria de Salud; Estrategia de Salud Familiar; Salud del Niño

\section{References}

1. Caminal Homar J, Starfield B, Sánchez Ruiz E, Hermosilla Pérez E, Martín Mateo M. La atención primaria de salud y las hospitalizaciones por ambulatory care sensitive conditions en Cataluña. Rev Clin Esp (Barc) 2001; 201:501-7.

2. Clancy CM. The persistent challenge of avoidable hospitalizations. Health Serv Res 2005; 40:953-6.

3. Starfield B. Atenção primária: equilíbrio entre necessidades de saúde, serviços e tecnologia. Brasília: Organização das Nações Unidas para a Educação, a Ciência e a Cultura/Ministério da Saúde; 2002.

4. Ministério da Saúde. Portaria no 2.488/GM de 21 de outubro de 2011, que aprova a Política Nacional de Atenção Básica. Diário Oficial da União 2011; 24 out.

\section{Contributors}

S. C. Carvalho participated in the project design and literature review, in the production, analysis, interpretation and discussion of the data and in the writing and final approval of the present article. E. Mota participated in the project design, in the production, analysis, interpretation and discussion of the data and in the critical revision of the style and content of the article and its final approval. I. Dourado e R. Aquino participated in the discussion of the project and the critical revision of the article. C. Teles participated in the discussion of the project, analysis and interpretation of the data and the critical revision of the article. M. G. Medina participated in the discussion of the project and the critical revision of the article.

\section{Acknowledgments}

The authors wish to thank Institute of Collective Health, Bahia Federal University and CNPq. S. C. Carvalho received grants from $\mathrm{CNPq}$.
5. Caminal Homar J, Morales Espinoza M, Sánchez Ruiz E, Cubells Larrosa MJ, Bustins Poblet M. Hospitalizaciones prevenibles mediante una atencion primaria oportuna y efectiva. Aten Primaria 2003; 31:6-17.

6. Alfradique ME, Bonolo PF, Dourado I, Lima-Costa MF, Macinko J, Mendonça CS, et al. Internações por condições sensíveis à atenção primária: a construção da lista brasileira como ferramenta para medir o desempenho do sistema de saúde (Projeto ICSAP - Brasil). Cad Saúde Pública 2009; 25:1337-49.

7. Billings J, Zeitel L, Lukomnik J, Carey TS, Blank AE, Newman L. Impact of socioeconomic status on hospital use in New York City. Health Aff (Millwood) 1993 ; 12:162-73. 
8. Ministério da Saúde. Portaria no 221/SAS de 17 de abril de 2008, que define a lista brasileira de internações por condições sensíveis à atenção primária. Diário Oficial da União 2008; 18 abr.

9. Nedel FB, Facchini LA, Martín-Mateo M, Vieira LAS, Thumé E. Programa Saúde da Família e condições sensíveis à atenção primária, Bagé (RS). Rev Saúde Pública 2008; 42:1041-52.

10. Fernandes VBL, Caldeira AP, Faria AA, Rodrigues Neto JF. Internações sensíveis na atenção primária como indicador de avaliação da Estratégia Saúde da Família. Rev Saúde Pública 2009; 43:928-36.

11. Nedel FB, Facchini LA, Martín M, Navarro A. Características da atenção básica associadas ao risco de internar por condições sensíveis à atenção primária: revisão sistemática da literatura. Epidemiol Serv Saúde 2010; 19:61-75.

12. Boing AF, Vicenzi RB, Magajewski F, Boing AC, Moretti-Pires RO, Peres KG, et al. Redução das internações por condições sensíveis à atenção primária no Brasil entre 1998-2009. Rev Saúde Pública 2012; 46:359-66.

13. Macinko J, Dourado I, Aquino R, Bonolo PF, LimaCosta MF, Medina MG, et al. Major expansion of primary care in Brazil linked to decline in unnecessary hospitalization. Health Aff (Millwood) 2010; 29:2149-60.

14. Dourado I, Oliveira VB, Aquino R, Bonolo PF, Lima-Costa MF, Medina MG, et al. Trends in primary health care-sensitive conditions in Brazil: the role of the Family Health Program (Project ICSAP-Brazil). Med Care 2011; 49:577-84.

15. Victora CG, Aquino EML, Leal MC, Monteiro CA, Barros FC, Szwarcwald CL. Maternal and child health in Brazil: progress and challenges. Lancet 2011; 377:1863-76.

16. Aquino R, Oliveira NF, Barreto, ML. Impact of the Family Health Program on infant mortality in Brazilian municipalities. Am J Public Health 2009; 99: 87-93.

17. Fundo das Nações Unidas para a Infância. Situação da infância brasileira 2006. Crianças de até 6 anos: direito à sobrevivência e ao desenvolvimento. Brasília: Fundo das Nações Unidas para a Infância; 2005.

18. Secretaria de Desenvolvimento Social e Direitos Humanos. Sistema de informação e gestão da assistência social de Pernambuco. http://portalso cial.sedsdh.pe.gov.br/sigas/Arquivos/Tabela\%20 dos\%20Munic\%EDpios.pdf (accessed em 02/Nov/ 2010).

19. Camero AC, Trivedi PK. Regression analysis of count data. Cambridge: Cambridge University Press; 1998.
20. Hilbe JM. Negative binomial regression. Cambridge: Cambridge University Press; 2007.

21. Silva AAM, Gomes UA, Tonial SR, Silva RA. Fatores de risco para hospitalização de crianças de um a quatro anos em São Luís, Maranhão, Brasil. Cad Saúde Pública 1999; 15:749-57.

22. Costa MCN, Azi PA, Paim JS, Silva LMV. Mortalidade infantil e condições de vida: a reprodução das desigualdades sociais em saúde na década de 90 . Cad Saúde Pública 2001; 17:555-67.

23. Fischer TK, Lima D, Rosa R, Osório D, Boing AF. A mortalidade infantil no Brasil: série histórica entre 1994-2004 e associação com indicadores socioeconômicos em municípios de médio e grande porte. Medicina (Ribeirão Preto) 2007; 40:559-66.

24. Macinko J, de Oliveira VB, Turci MA, Guanais FC, Bonolo PF, Lima-Costa MF. The influence of primary care and hospital supply on ambulatory caresensitive hospitalizations among adults in Brazil, 1999-2007. Am J Public Health 2011; 101:1963-70.

25. Campos AZ, Theme-Filha MM. Internações por condições sensíveis à atenção primária em Campo Grande, Mato Grosso do Sul, Brasil, 2000 a 2009. Cad Saúde Pública 2012; 28:845-55.

26. Caetano R, Dain S. O Programa de Saúde da Família e a reestruturação da atenção básica à saúde nos grandes centros urbanos: velhos problemas, novos desafios. Physis (Rio J.) 2002; 12:11-21.

27. Medina, MG Hartz ZMA. The role of the Family Health Program in the organization of primary care in municipal health systems. Cad Saúde Pública 2009; 25:1153-67.

28. Bittencourt AS, Camacho LAB, Leal MC. O Sistema de Informação Hospitalar e sua aplicação na saúde coletiva. Cad Saúde Pública 2006; 22:19-30.

29. Guanais FC. Municipal-level covariates of health status in Brazil: a proposed method for data interpolation. Rev Panam Salud Pública 2013; 34:190-7.

30. Rasella D, Aquino R, Barreto ML. Reducing childhood mortality from diarrhea and lower respiratory tract infections in Brazil. Pediatrics 2010; 126:534-40.

31. Caldeira AP, Fernandes VBL, Fonseca WP, Faria AA. Internações pediátricas por condições sensíveis à atenção primária em Montes Claros, Minas Gerais, Brasil. Rev Bras Saúde Matern Infant 2011; 11: 61-71.

32. Barreto JOM, Nery IS, Costa MSC. Estratégia Saúde da Família e internações hospitalares em menores de 5 anos no Piauí, Brasil. Cad Saúde Pública 2012; 28:515-26.

Submitted on 04/May/2014

Final version resubmitted on 10/Sep/2014

Approved on 18/Sep/2014 